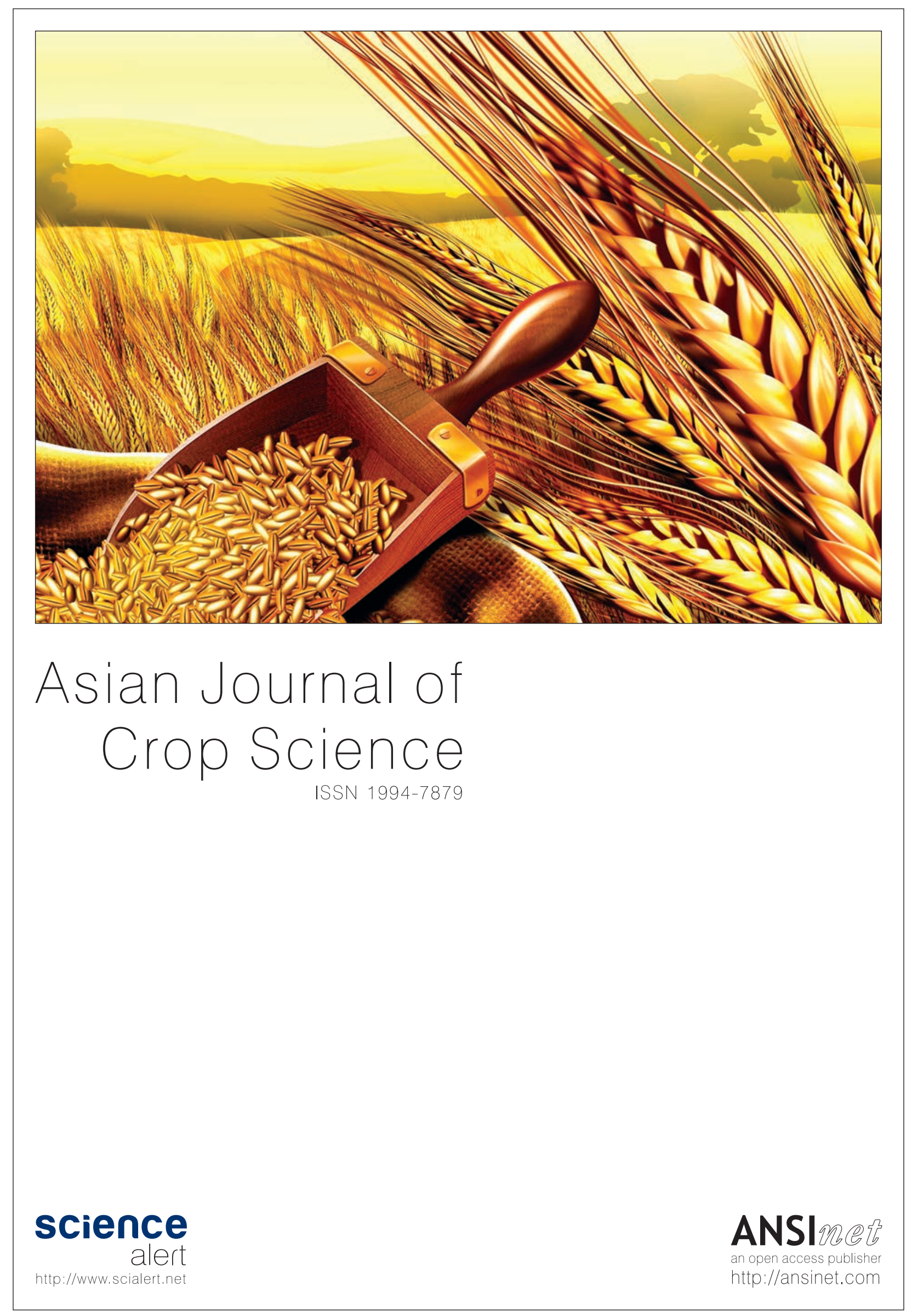




\title{
Characteristics Yield of Soybean (Glycine max (L.) Merrill) with Application of Bokashi Fertilizer and Mycorrhiza Fungi on Marginal Dry Lands
}

\author{
Sarawa and Halim \\ Department of Agrotechnology, Faculty of Agriculture, Halu Oleo University, Kendari, Southeast Sulawesi, Indonesia
}

\section{Abstract}

Background and Objective: The use of marginal dry land is one strategy to overcome the limited soil fertility. Indonesia has marginal dry land of around 102.8 million ha, most of which are podsolite red yellow (PRY) or Ultisol whose distribution reaches 45.794 .000 ha or about $25 \%$ of the total land area in Indonesia. This study aims to determine the characteristics yield of soybean after being treatment with bokashi fertilizer and mycorrhiza fungi on marginal dry land. Materials and Methods: This study was used the randomized block design in factorial pattern consisting of 2 factors i.e., doses of bokashi fertilizer consisting of 4 levels, without fertilizer $\left(\mathrm{S}_{0}\right)$, bokashi fertilizer 5 tha $^{-1}\left(S_{1}\right)$, bokashi fertilizer 10 tha $^{-1}\left(S_{2}\right)$, bokashi fertilizer 15 tha $^{-1}\left(S_{3}\right)$ and second factor is arbuscular mycorrhiza fungi (AMF) consisting of 4 levels, without AMF $\left(M_{0}\right)$, AMF $5 \mathrm{~g} /$ planting hole $\left(M_{1}\right)$, AMF $10 \mathrm{~g} /$ planting hole $\left(M_{2}\right)$, AMF $15 \mathrm{~g} /$ planting holes $\left(M_{3}\right)$. The parameters observed: Number of pods, number of seed/plants, weight of 1000 seeds and production $\left(t^{~ h a}{ }^{-1}\right)$. Results: The results showed that the combination of bokashi fertilizer with the AMF had an effect on the number of pods and seeds number/planting. The highest soybean yield was obtained in a combination of bokashi fertilizer at doses $15 \mathrm{tha} \mathrm{a}^{-1}$ and AMF $15 \mathrm{~g} /$ planting hole $\left(\mathrm{S}_{3} \mathrm{M}_{3}\right)$ as $1.59 \mathrm{t} \mathrm{ha}^{-1}$. Conclusion: The combination of bokashi fertilizer at doses $15 \mathrm{t} \mathrm{ha}^{-1}$ with AMF $15 \mathrm{~g} /$ planting hole gave the highest yield as $1.59 \mathrm{t} \mathrm{ha}^{-1}$.

Key words: Bokashi fertilizer, mycorrhiza fungi, soybean, marginal dry land, soil fertility

Citation: Sarawa and Halim, 2020. Characteristics yield of soybean (Glycine max (L.) Merrill) with application of bokashi fertilizer and mycorrhiza fungi on marginal dry lands. Asian J. Crop Sci., 12: 51-56.

Corresponding Author: Halim, Department of Agrotechnology, Faculty of Agriculture, Halu Oleo University, Kendari, Southeast Sulawesi, Indonesia

Copyright: @ 2020 Sarawa and Halim. This is an open access article distributed under the terms of the creative commons attribution License, which permits unrestricted use, distribution and reproduction in any medium, provided the original author and source are credited.

Competing Interest: The authors have declared that no competing interest exists.

Data Availability: All relevant data are within the paper and its supporting information files. 


\section{INTRODUCTION}

The use of marginal dry land is one strategy to overcome the limited soil fertility. Indonesia has marginal dry land of around 102.8 million ha', most of which are podsolite red yellow (PRY) or Ultisol whose distribution reaches 45.794 .000 ha or about 25\% of the total land area in Indonesia ${ }^{2}$. Therefore, this type of land has an important role in the development of agriculture on marginal dry land in Indonesia. The types of soil included in the Ultisol order generally have a low fertility rate caused by macro nutrient poor ( $\mathrm{N}, \mathrm{P}, \mathrm{K}, \mathrm{Ca}, \mathrm{Mg}, \mathrm{S})$, micro nutrient $(\mathrm{Zn}, \mathrm{Mo}, \mathrm{Cu}, \mathrm{B})$ and low levels of organic matter ${ }^{3-5}$. The Ultisol has a low $\mathrm{pH}(<5.5)$ which causes high content of $\mathrm{Al}$, Fe and $\mathrm{Mn}$ dissolved in the soil so that it can toxic to plants. The high level of $P$ fixation, erosion-sensitive nature of the soil and biotic factors also become obstacles in the use of marginal dry land ${ }^{6}$.

The productivity of soybean on marginal dry land, especially in Southeast Sulawesi still relatively low with an average production as $1.1 \mathrm{t} \mathrm{ha}^{-1}$ and still lower than the national production that reached as $1.35 \mathrm{t} \mathrm{ha}^{-1}$. The main obstacles to soybean production on marginal dry land are high levels of soil acidity Al and Fe have high solubility, low organic matter content, lack of nutrients and low cation exchange capacity ${ }^{7}$.

The efforts to increasing the fertility of marginal dry land have been done in various ways including the use of organic fertilizers such as manure. However, the use of manure is increasingly difficult because the price is getting more expensive and the availability is increasingly limited so attention is diverted to bokashi fertilizer which is sourced from abundant sago pulp and becomes waste. Sago pulp contains high organic ingredients and more complex macro and micro nutrients. According to Syakir ${ }^{8}$, nutrient content of bokashi from sago waste consists of $47 \% \mathrm{C}, 2.25 \% \mathrm{~N}, 0.31 \% \mathrm{P}, 0.08 \% \mathrm{~K}$, $\mathrm{C} / \mathrm{N}$ ratio as 18.76 and calcium and magnesium. The sago pulp that has accumulated for years will experience decomposition so that it can release a number of nutrients for plants ${ }^{9}$. The sago pulp that has undergone a decomposition process will release nutrients of $\mathrm{N}, \mathrm{P}, \mathrm{K}, \mathrm{Ca}$ and $\mathrm{Mg}$ which is bound so that these nutrients become available to plants ${ }^{10}$. In addition, sago pulp is also able to improve soil structure and fertility, can meet the lack of organic matter and nutrients and increase water availability.

The effort to optimize the function of bokashi fertilizer in releasing nutrient bonds, especially $\mathrm{P}$ nutrient elements, it is necessary to apply microorganisms such as mycorrhiza fungi ${ }^{11,12}$. This is in accordance with the opinion of Masria ${ }^{13}$, that to overcome drought stress and P deficiency in marginal soils it is necessary to use mycorrhiza fungi. The working principle of mycorrhiza fungi is to infect the root system of host plants and produce intricate hyphae so that the roots of plants infected with mycorrhizal fungi will be able to increase the capacity of nutrient absorption and water ${ }^{14}$, increasing the availability of various growth hormones needed by plants ${ }^{15}$ and plants are resistant to attack by root pathogens ${ }^{1}$. Based on this description, the objective is to study the effect of bokashi fertilizers and arbuscular mycorrhiza fungi on the growth and yield of soybean on marginal dry land.

\section{MATERIAL AND METHODS}

Study area: This study was conducted at Field Laboratory of Agriculture Faculty, Halu Oleo University, Indonesia. The total research duration was from March, 23 to November 16, 2019.

Bokashi fertilizer setup: The Bokashi fertilizer was made by inserting sago pulp into wooden tub in size $2 \times 1 \mathrm{~m}$ and it has been coated with a plastic tent. Each thickness in $20 \mathrm{~cm}$ doused with effective microorganism-4 (EM-4) solution and sugar as $10 \mathrm{~g}$ in $1 \mathrm{~L}$ of water. The wooden tub containing sago pulp was closed (15-20 cm in thickness) covered with plastic. Every 2 days a temperature check and reversal is carried out $\left(40-50^{\circ} \mathrm{C}\right)$ until bokashi mature after $10-14$ days.

Field research setup: The land setup starts with clearing land from secondary vegetation and plant debris, then processing the soil. The tillage is done twice namely the first tillage using a hand tractor with $15-20 \mathrm{~cm}$ in depth, followed by the second processing using a hoe to loosen and flatten the soil. The next step is making the experimental plots with $2 \times 1.5 \mathrm{~m}$ in size as number 48 plots. The plot distance in groups is $50 \mathrm{~cm}$ and the group distance is $75 \mathrm{~cm}$.

The study was used the randomized block design (RBD) in factorial pattern consisting of 2 factors. The first factor is: Bokashi fertilizer consisting of 4 levels, namely: Without fertilizer $\left(S_{0}\right)$, bokashi fertilizer with a dose of $5 \mathrm{tha}^{-1}\left(\mathrm{~S}_{1}\right)$, bokashi fertilizer with a dose of $10 \mathrm{tha}^{-1}\left(\mathrm{~S}_{2}\right)$ and bokashi fertilizer with a dose $15 \mathrm{t} \mathrm{ha}^{-1}\left(\mathrm{~S}_{3}\right)$. The second factor is arbuscular mycorrhiza fungi propagules consisting of 4 levels, namely: Without mycorrhiza fungi propagules $\left(M_{0}\right)$, mycorrhiza fungi propagules as $5 \mathrm{~g} /$ planting hole $\left(M_{1}\right)$, mycorrhiza fungi propagules as $10 \mathrm{~g} /$ planting hole $\left(M_{2}\right)$ and mycorrhiza fungi propagules as $15 \mathrm{~g} /$ planting holes $\left(M_{3}\right)$. Each treatment was repeated 3 times so that there were 48 experimental units. 
The application of bokashi fertilizer is carried out in an array between rows of plants one week before planting according to the treatment dose. The soybean seeds of Anjasmoro variety with $80 \%$ germination. The planting is done using holling as deep as $\pm 3 \mathrm{~cm}$, each hole is inserted into 4 soybean seeds, planting space of $40 \times 20 \mathrm{~cm}$. The application of mycorrhiza fungi propagules was carried out at the same time as soybean planting. Thinning is carried out at the age of 7 days after planting and only allowed to grow one perforated plant. Watering is done every day with the same flush volume for each plot if it doesn't rain.

Observation variable: The variables observed in this study included: Pods number/plant, seeds number, weight of 1.000 seeds ( $\pm 14 \%$ water content) and crop production of $\mathrm{t} \mathrm{ha}^{-1}$.

Statistical analysis: The data of observation was analyzed using the variety of variance according to the design used. If the variance shows the real effect will be continued with the honestly significance difference (HSD) at 95\% confidence level.

\section{RESULTS}

Pods number: The results analysis of variance showed that the treatment of bokashi fertilizer and mycorrhiza fungi had a very significant effect on the pods number of soybean.

Table 1 showed that the combination of bokashi fertilizer and mycorrhiza fungi affected the number of soybean pods. The highest number of pods was obtained from a combination treatment of bokashi fertilizer as $15 \mathrm{t} \mathrm{ha}^{-1}$ with mycorrhiza fungi propagules as $15 \mathrm{~g} /$ planting hole $\left(\mathrm{S}_{3} \mathrm{M}_{3}\right)$ as 51.17 pods and it was not significant with treatment of bokashi fertilizer as $10 \mathrm{t} \mathrm{ha}^{-1}$ with mycorrhiza fungi as $15 \mathrm{~g} /$ planting hole $\left(\mathrm{S}_{2} \mathrm{M}_{3}\right)$, treatment of $15 \mathrm{t} \mathrm{ha}^{-1}$ with mycorrhiza fungi as $5 \mathrm{~g} /$ planting hole $\left(\mathrm{S}_{3} \mathrm{M}_{1}\right)$ and treatment of $15 \mathrm{tha}^{-1}$ with mycorrhiza fungi propagules as $10 \mathrm{~g} /$ planting hole $\left(S_{3} M_{2}\right)$, but it was significantly different from controls $\left(\mathrm{S}_{0} \mathrm{M}_{0}\right)$.

Seeds number: Table 2 showed that the combination of bokashi fertilizer and mycorrhiza fungi propagules had an effect on the number of soybean seeds. The highest number of soybean seeds obtained in the combination of $\mathrm{S}_{3} \mathrm{M}_{3}$ treatment was 146.42 seeds which were not significantly different from the combination of treatment $\mathrm{S}_{2} \mathrm{M}_{3}$ as much as 112.33 seeds, $\mathrm{S}_{3} \mathrm{M}_{2}$ as many as 124.25 and $\mathrm{S}_{3} \mathrm{M}_{1}$ as many as 109.42 seeds, but different from other treatment combinations.

Weight of 1.000 seeds: The analysis of variance showed that the treatment of bokashi fertilizer and mycorrhizal fungi had very significant effect on the weight of 1.000 seeds.

Table 3 shows that the treatment of bokashi fertilizer has a significant effect on the weight of 1.000 soybeans. The average highest weight was obtained in treatment of bokashi fertilizer $15 \mathrm{t} \mathrm{ha}^{-1}$ and propagules arbuscular mycorrhiza fungi $15 \mathrm{~g} /$ planting hole $\left(\mathrm{S}_{3} \mathrm{M}_{3}\right)$ as $88.32 \mathrm{~g}$ which it was not significantly different from with treatment of $\mathrm{S}_{3} \mathrm{M}_{2}$ as $84.48 \mathrm{~g}$, but it was significantly different from with other treatments.

Table 1: Effect of organic fertilizers and mycorrhiza fungi on the pods number/plant

\begin{tabular}{|c|c|c|c|c|}
\hline \multirow[b]{2}{*}{ Bokashi fertilizer } & \multicolumn{4}{|c|}{ Mycorrhiza fungi propagules (g) } \\
\hline & Without AMF $\left(M_{0}\right)$ & AMF $5 \mathrm{~g} /$ planting hole $\left(\mathrm{M}_{1}\right)$ & AMF $10 \mathrm{~g} /$ planting hole $\left(\mathrm{M}_{2}\right)$ & AMF $15 \mathrm{~g} /$ planting hole $\left(\mathrm{M}_{3}\right)$ \\
\hline Without fertilizer $\left(\mathrm{S}_{0}\right)$ & $26.25^{\mathrm{d}, \mathrm{r}}$ & $27.42^{\mathrm{d}, \mathrm{r}}$ & $30.00^{c, q}$ & $31.00^{\mathrm{c}, \mathrm{q}}$ \\
\hline Bokashi fertilizer $5 \mathrm{t} \mathrm{ha}^{-1}\left(\mathrm{~S}_{1}\right)$ & $26.67^{\mathrm{d}, \mathrm{r}}$ & $29.25^{c, r}$ & $30.25^{\mathrm{c}, q}$ & $31.83^{\mathrm{b}, \mathrm{q}}$ \\
\hline Bokashi fertilizer $10 \mathrm{tha}^{-1}\left(\mathrm{~S}_{2}\right)$ & $28.50^{c, r}$ & $30.92^{c, q}$ & $34.42^{\mathrm{b}, \mathrm{q}}$ & $40.17^{\mathrm{c}, \mathrm{p}}$ \\
\hline Bokashi fertilizer $15 \mathrm{tha}^{-1}\left(\mathrm{~S}_{3}\right)$ & $31.83^{9}$ & $39.67^{\mathrm{a}, \mathrm{p}}$ & $43.92^{\mathrm{a}, \mathrm{p}}$ & $51.17^{\mathrm{a}, \mathrm{p}}$ \\
\hline
\end{tabular}

Numbers followed by unequal letters differ significantly with honestly significance difference (HSD) at 95\% confidence level

Table 2: Effect of Bokashi fertilizer and mycorrhiza fungi on seeds number (grain)/plant

\begin{tabular}{|c|c|c|c|c|}
\hline \multirow[b]{2}{*}{ Bokashi fertilizer } & \multicolumn{4}{|c|}{ Mycorrhiza fungi propagules (g) } \\
\hline & Without AMF $\left(M_{0}\right)$ & AMF $5 \mathrm{~g} /$ planting hole $\left(\mathrm{M}_{1}\right)$ & AMF $10 \mathrm{~g} /$ planting hole $\left(\mathrm{M}_{2}\right)$ & AMF $15 \mathrm{~g} /$ planting hole $\left(\mathrm{M}_{3}\right)$ \\
\hline Without fertilizer $\left(\mathrm{S}_{0}\right)$ & $64.42^{\mathrm{d}, \mathrm{s}}$ & $69.42^{\mathrm{d}, \mathrm{s}}$ & $79.08^{c, q}$ & $79.92^{c, q}$ \\
\hline Bokashi fertilizer $5 \mathrm{t} \mathrm{ha}^{-1}\left(\mathrm{~S}_{1}\right)$ & $66.83^{\mathrm{d}, \mathrm{s}}$ & $75.33^{c, r}$ & $81.67^{\mathrm{c}, q}$ & $86.00^{\mathrm{b}, \mathrm{q}}$ \\
\hline Bokashi fertilizer $10 \mathrm{t} \mathrm{ha}^{-1}\left(\mathrm{~S}_{2}\right)$ & $73.25^{\mathrm{c}, \mathrm{r}}$ & $83.33^{c, q}$ & $95.83^{\mathrm{b}, \mathrm{q}}$ & $112.33^{b, q}$ \\
\hline Bokashi fertilizer $15 \mathrm{t} \mathrm{ha}^{-1}\left(\mathrm{~S}_{3}\right)$ & $83.75^{\mathrm{c,q}}$ & $109.42^{\mathrm{a}, \mathrm{p}}$ & $124.25^{\mathrm{a}, \mathrm{p}}$ & $146.42^{\mathrm{a}, \mathrm{p}}$ \\
\hline
\end{tabular}

Numbers followed by unequal letters differ significantly with honestly significance difference (HSD) at 95\% confidence level 
Table 3: Effect of Bokashi fertilizer and mycorrhiza fungi on 1.000 seeds

\begin{tabular}{|c|c|c|c|c|}
\hline \multirow[b]{2}{*}{ Bokashi fertilizer } & \multicolumn{4}{|c|}{ Mycorrhiza fungi propagules (g) } \\
\hline & Without AMF $\left(M_{0}\right)$ & AMF $5 \mathrm{~g} /$ planting hole $\left(\mathrm{M}_{1}\right)$ & AMF $10 \mathrm{~g} /$ planting hole $\left(\mathrm{M}_{2}\right)$ & AMF $15 \mathrm{~g} /$ planting hole $\left(\mathrm{M}_{3}\right)$ \\
\hline Without fertilizer $\left(\mathrm{S}_{0}\right)$ & 66.93 & 71.67 & 72.45 & 74.74 \\
\hline bokashi fertilizer $5 \mathrm{t} \mathrm{ha}^{-1}\left(\mathrm{~S}_{1}\right)$ & 70.27 & 72.16 & 75.43 & 77.81 \\
\hline bokashi fertilizer $10 \mathrm{tha}^{-1}\left(\mathrm{~S}_{2}\right)$ & 74.58 & 87.56 & 88.25 & 94.55 \\
\hline bokashi fertilizer $15 \mathrm{tha}^{-1}\left(\mathrm{~S}_{3}\right)$ & 81.05 & 91.93 & 101.79 & 106.19 \\
\hline Average & $73.21^{c}$ & $80.83^{b}$ & $84.48^{\mathrm{ab}}$ & $88.32^{\mathrm{a}}$ \\
\hline
\end{tabular}

Numbers followed by unequal letters differ significantly with honestly significance difference (HSD) at $95 \%$ confidence level

Table 4: Effect of organic fertilizer and mycorrhiza fungi on seed production ( $\mathrm{tha}^{-1}$ )

\begin{tabular}{|c|c|c|c|c|c|}
\hline \multirow[b]{2}{*}{ Bokashi fertilizer } & \multicolumn{5}{|c|}{ Mycorrhiza fungi propagules (g) } \\
\hline & Without AMF $\left(M_{0}\right)$ & AMF $5 \mathrm{~g} /$ planting hole $\left(\mathrm{M}_{1}\right)$ & AMF $10 \mathrm{~g} /$ planting hole $\left(\mathrm{M}_{2}\right)$ & AMF $15 \mathrm{~g} /$ planting hole $\left(\mathrm{M}_{3}\right)$ & Average \\
\hline Without fertilizer $\left(\mathrm{S}_{0}\right)$ & 1.00 & 1.08 & 1.09 & 1.12 & $1.07^{c}$ \\
\hline Organic fertilizer $5 \mathrm{t} \mathrm{ha}^{-1}\left(\mathrm{~S}_{1}\right)$ & 1.05 & 1.08 & 1.13 & 1.17 & $1.11^{c}$ \\
\hline Bokashi fertilizer $10 \mathrm{t} \mathrm{ha}^{-1}\left(\mathrm{~S}_{2}\right)$ & 1.12 & 1.31 & 1.32 & 1.42 & $1.29^{b}$ \\
\hline Bokashi fertilizer $15 \mathrm{t} \mathrm{ha}^{-1}\left(\mathrm{~S}_{3}\right)$ & 1.22 & 1.38 & 1.30 & 1.59 & $1.37^{\mathrm{a}}$ \\
\hline Average & $1.10^{c}$ & $1.21^{\mathrm{b}}$ & $1.21^{\mathrm{b}}$ & $1.33^{\mathrm{a}}$ & \\
\hline
\end{tabular}

Numbers followed by unequal letters differ significantly with honestly significance difference (HSD) at 95\% confidence level

Seed production (t ha- $\left.\mathbf{~ h}^{-1}\right)$ : The analysis of variance showed that treatment of organic fertilizer and mycorrhiza fungi had very significant effect on soybean seed production.

Table 4 shows that the treatment of bokashi fertilizer has a significant effect on the weight of soybean seeds. The highest seed weight was obtained in treatment of $\mathrm{S}_{3}$ which was significantly different from the other treatments. Whiles the highest application of mycorrhiza fungi was obtained in $\mathrm{M}_{3}$ treatment which was significantly different from with other treatments.

\section{DISCUSSION}

The application of bokashi fertilizer as $15 \mathrm{t} \mathrm{ha}^{-1}$ and mycorrhiza fungi as $15 \mathrm{~g} /$ planting hole $\left(\mathrm{S}_{3} \mathrm{M}_{3}\right)$ gave the highest number of pods as 51.17 pods. This shows that bokashi fertilizer and mycorrhiza fungi can work in synergy in increasing the number of soybean pods. The results of research ${ }^{16}$ that compost, inoculum of mycorrhiza fungi and Nitrogen fertilizer can increase the number of pods in soybean plants. The need for soybean plants for Nitrogen is greater because it plays a role in the formation of chlorophyll, amino acids, proteins and stimulates the development of roots and increases absorption of other nutrients. The nutrient $P$ can stimulate the formation of new cells, including roots so that it will expand the absorption area of nutrients. According to Melati and Wisdiyastuti ${ }^{17}$, sufficient nutrient content and being able to increase $\mathrm{P}$ availability in plants can increase vegetative and generative growth of soybean plants. The treatment with the application of organic fertilizers and mycorrhiza fungi tended to increase the average number of pods/plant compared to the control.

The provision of organic fertilizer tends to increase the carrying capacity or soil environment of plants so that the process of growth and development runs better including nutrient exploration. The depletion of nutrient content in the soil causes a decrease in the ability of plants to maintain the growth and development of vegetative organs, so that nutrient distribution and photosynthates tend to be directed to generative organs. The decreased ability causes the number of vegetative organs to die, thus inhibiting the process of translocation of nutrients to leaves, decreasing photosynthates and decreasing the ability of plants to form filled pods.

The results of research showed that the combination of bokashi fertilizer as $15 \mathrm{tha}^{-1}$ and mycorrhiza fungi at a dose of $15 \mathrm{~g} /$ planting hole $\left(\mathrm{M}_{3} \mathrm{~S}_{3}\right)$ gave the highest number of seeds as 146.42 seeds. This is an indication that the nutrient content of fertilizers and mycorrhiza fungi can increase growth, the seeds number and the yield of dried seeds. According to Marlina ${ }^{18}$, soybean seed yields are basically determined by photosynthesis in the flowering period. The increase in the yield of dried soybeans fertilized with organic fertilizers is thought to be due to the increased number of photosynthates distributed in seeds during the seed filling phase. The soybean needs for nutrients are classified based on the amount of nutrient requirements in each phase. The growth and development phases that most require nutrients are known as the critical phase of plants. 
The period of seed formation is one of the critical phases of plants. In this phase plants need nutrients in large quantities to stimulate perfect growth and development of seeds. The lack of nutrients causes the seed initiation process to not be perfect, so the results are not optimal. This is similarity with the statement Tandon and Sekhon ${ }^{19}$, soybean plants need a lot of nutrients, especially N, P, K. The soybean seeds accumulate a large amount of assimilates that are rich in protein (about 40\%), nitrogen nutrients are needed in the formation of proteins. Similarly, the statement of Sheppards and Bates ${ }^{20}$, that Nitrogen is needed especially in the period of pod formation and seed filling.

The combination of bokashi fertilizer and mycorrhiza fungi at various dosage levels did not affect the weight of 1.000 seeds. The formation of seeds and seed weight in plants is very dependent on the availability of sufficient phosphorus in the soil because Phosphorus is very influential on the growth of generative plants, especially the formation of flowers, pods, seeds and seed weight. Phosphorus nutrients play a role in the generative part of the plant, especially in filling seeds. There is the ability of mycorrhiza fungi to dissolve phosphorus very helpful in increasing the availability of phosphorus in marginal dry land. The ability of mycorrhiza fungi to dissolve phosphorus is caused because mycorrhizal fungi can release a number of organic acids which then release bound phosphorus. This is consistent with what was stated by Sagoe et al.21 that's the ability to dissolve phosphate by microbes is due to its ability to release organic acids from microbes so that these organic acids dissolve $\mathrm{P}$ bonds by hydroxyl and carboxyl groups which eventually become available $P$. This is accordance with the application of mycorrhiza fungi gave the best results on parameters of flowering age, number of pods, dry seed production and seed weight ${ }^{22}$.

The combination of bokashi fertilizer at dose of $15 \mathrm{t} \mathrm{ha}^{-1}$ with mycorrhiza fungi at dose of $15 \mathrm{~g} /$ planting hole gave the highest yield as $1.59 \mathrm{t} \mathrm{ha}^{-1}$. There is a significant increase in yield of soybean crops due to the giving of organic fertilizer in general can increase nutrient availability in plants so that plant growth and production can be increased. In general, the addition of $15 \mathrm{tha}^{-1}$ organic fertilizer can provide better vegetative growth and components of soybean production ${ }^{23}$. This is in fact in line with the results of the study reported by Khadijah 22 that's the application of AMF at a dose of $10 \mathrm{~g} /$ polybag gave the best results on flowering age, number of pods, dry seed production and weight of 100 seeds.

The plants that symbiosing with mycorrhiza fungi have the ability to absorb nutrients and higher water because of the presence of mycorrhiza fungi hyphae. In addition, mycorrhiza fungi can dissolve phosphate so that the availability of phosphorus in the soil increases. The nutrient phosphate is very necessary in the metabolic process of plants, among others, to stimulate plant growth, root development, fruit growth, improve quality and strengthen resistance to insect pests and diseases ${ }^{24}$. Another advantage due to the administration of mycorrhizal fungi is their ability to produce growth hormones for plants so they can increase yields on soybean. This is in line with the statement of Goenarto ${ }^{25}$, that's the presence of hormones around plant roots will help the process of division and enlargement so that plant roots become more active in the process of absorption of water and nutrients.

\section{CONCLUSION}

The application of bokashi fertilizer as $15 \mathrm{t} \mathrm{ha}^{-1}$ and arbuscular mycorrhiza fungi as $15 \mathrm{~g} /$ planting hole $\left(\mathrm{S}_{3} \mathrm{M}_{3}\right)$ gave the highest number of pods as 51.17 pods. The results of research showed that the combination of bokashi fertilizer as $15 \mathrm{t} \mathrm{ha}^{-1}$ and arbuscular mycorrhiza fungi at a dose of $15 \mathrm{~g} /$ planting hole $\left(\mathrm{M}_{3} \mathrm{~S}_{3}\right)$ gave the highest number of seeds as 146.42 seeds. The combination of bokashi fertilizer at dose of $15 \mathrm{tha}^{-1}$ with arbuscular mycorrhiza fungi at dose of $15 \mathrm{~g} /$ planting hole gave the highest yield as $1.59 \mathrm{t} \mathrm{ha}^{-1}$.

\section{SIGNIFICANCE STATEMENT}

This study discovered that combination of bokashi fertilizer and arbuscular mycorrhiza fungi can be improved and increase the growth and yield of soybean in marginal dry land. The combination of bokashi fertilizer at dose of $15 \mathrm{tha}^{-1}$ with mycorrhiza fungi at dose of $15 \mathrm{~g} /$ planting hole gave the highest yield as $1.59 \mathrm{tha}^{-1}$. This study will help the researcher to uncover the marginal dry land for soybean planting that many researchers were not able to explore the bokashi fertilizer from agricultural waste and arbuscular mycorrhiza fungi as integrated fertilizer. Thus, a new theory on combination bokashi fertilizer and arbuscular mycorrhiza fungi as strategies may be arrived at.

\section{REFERENCES}

1. Mulyani, A., Hikmatullah and H. Subagya, 2003. Karakteristik dan potensi tanah masam lahan kering di Indonesia. Prosidings Simposium Nasional Pendayagunaan Tanah Masam, September 29-30, 2003, Bandar Lampung.

2. Subagyo, H., N. Suharta and A.B. Siswanto, 2004. Tanah-Tanah Pertanian di Indonesia. Pusat Penelitian Tanah dan Agroklimat, Bogor, pp: 21-66. 
3. Conyers, M.K., D.P. Heenan, W.J. McGhie and G.P. Poile, 2003. Amelioration of acidity with time by limestone under contrasting tillage. Soil Tillage Res., 72: 85-94.

4. Costa, A. and C.A. Rosolem, 2007. Liming in transition to no-till under a wheat-soybean rotation. Soil Tillage Research, 97: 207-217.

5. Caires, E.F., F.J. Garbuio, S. Churka, G. Barth and J.C.L. Coreea, 2008. Effects of soil acidity amelioration by surface liming on no-till corn, soybean and wheat root growth and yield. Eur. J. Agron., 28: 57-64.

6. Mulyani, A., 2006. Potensi lahan kering masam untuk pengembangan pertanian. Warta Penelitian Pengembangan Pertanian, 28: 16-17.

7. Sudaryono, Wijanarko, Andy and Suyatmo, 2011. Effect of combination of ameliorant and manure on soybean grain yield in ultisol soil. J. Penelitian Pertanian Tanaman Pangan, 30: 43-51.

8. Syakir, M., 2010. Pengaruh waktu pengomposan dan limbah sagu terhadap kandungan hara, asam fenolat dan lignin. Institut Pertanian Bogor, Indonesia.

9. Syahtria, I.K., Sampoerno and Wardati, 2016. Effect of sago waste compost on the growth of oil palm (Elaeis guineensis Jacq) in the main seedling. Jom Faperta, 2: 1-9.

10. Zaimah, F. and E. Prihastanti, 2012. Test the use of sago waste compost on growth strawberry (Fragaria vesca L.) in Plajan village, Jepara regency. Buletin Anatomi Fisiol., 20: 18-28.

11. Lingga, P. and Marsono, 2008. Petunjuk Penggunaan Pupuk. Penebar Swadaya Grup, Jakarta, Indonesia, ISBN: 978-979-002-588-2, Pages: 162.

12. Prihastuti, 2007. Isolation and characterization of vesicular-arbuscular mycorrhizae collected from acid dry land of central lampung. Berk. Penel. Hayati, 12: 99-106.

13. Masria, 2015. Exploiting of Mycorrhiza Vesicular Arbuscular (MVA) to increase crop resistance to dryness grasp and availability of $P$ at dry farming. Partner, 15: 48-56.

14. Rungkat, J.A., 2009. The role of mycorrhiza vesicular arbuscular in increasing plant growth and production. J. Formas, 4: 270-276.
15. Turmuktini, T., 2009. Interaction between the dose of arbuscular mycorrhizal fungi on growth, quantity and quality of three soybean cultivars. Ber. Hayati Edisi Khusus, 3: 79-83.

16. Triadiati, N.R. Mubarik and R. Yoan, 2013. Growth response of soybean to acid tolerant Bradyrhizobium japonicum and fertilizers application in acid soil. J. Agron. Indones., 41: 24-31.

17. Melati, M. and A. Wisdiyastuti, 2005. The effect of chicken manure and green manure Calopogonium mucunoides on growth and production of vegetable soybean under organic farming system. Bul. Agron., 33: 8-15.

18. Marlina, 2012. The effect of organic fertilizer on growth and yield of soybean plant. J. Agroqua, 10: 13-16.

19. Tandon, H.L.S. and G.S. Sekhon, 1998. Potassium Research and Agricultural Production in India. Fertililiser Development and Consultation Organisation, India, Pages: 144.

20. Sheppards, S.C. and T.E. Bates, 1980. Yield and chemical composition of rape in response to nitrogen, phosphorus and potassium. Can. J. Soil Sci., 60: 153-162.

21. Sagoe, C.I., T. Ando, K. Kouno and T. Nagaoka, 1998. Relative importance of protons and solution calcium concentration in phosphate rock dissolution by organic acids. Soil Sci. Plant Nutr., 44: 617-625.

22. Khadijah, S., 2017. Respons tanaman kedelai (Glicine max (L.) pada aplikasi cendawan mikoriza arbuscula (CMA) dan Pupuk Organik Cair (POC). Skripsi, Program Studi Agroteknologi. Departemen Budidaya Pertanian. Universitas Hasanuddin Makassar, Indonesia.

23. Sudarsono, W.F., M. Melati and S.A. Aziz, 2013. Growth, nutrient uptake and yield of organic soybean with cow manure application. J. Agron. Indones., 41: 202-208.

24. Wicaksono, M.I., M. Rahayu and Samanhudi, 2014. Effect of mycorrhizal and organic fertilizer on the growth of garlic. J. Ilmu-IImu Pertanian, 29: 35-44.

25. Goenarto, L., 2000. Microba rizosfer: Potensi dan manfaatnya. J. Penelitian Pengembangan Pertanian, 19: 39-48. 